\title{
鉄硫黄クラスターを含む金属酵素とそのモデル
}

\author{
中 村 晃* ·上 山憲 -*
}

\section{Fe-S Clusters in Metalloenzymes and in Their Model Complexes}

Akira NAKAMURA* and Norikazu UEYAMA *

\begin{abstract}
Recent developments in the chemistry of various types of $\mathrm{Fe}-\mathrm{S}$ clusters involved in biologically important metalloenzymes, e. g. aconitase, hydrogenase, nitrogenase and their model complexes, are reviewed. In particular, the magnetic interaction between the Fe-S clusters and the active site is emphasized. Importance of the $\mathrm{Fe}-\mathrm{S}$ clusters in the redox reactions via multielectron transfer is demonstrated.
\end{abstract}

\section{1.はじめに}

鉄硫黄 $(\mathrm{Fe}-\mathrm{S})$ クラスターは窒素固定酵素, 水素固定 酵素, あるいは $\mathrm{C}-\mathrm{H}$ の酸化酵素など多電子移動の反応 を行う酵素の活性部位の近くに存在し, 重要な役割をし

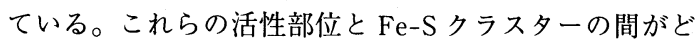
のようにしてつながっているかは重要な問題であり, 同 じような機能を持つ新型触媒の開発研究を行うには当然 解決しておかなければならない課題である。この両者を つないでいる型に 2 種類ある。一つは活性部位 (金属イ

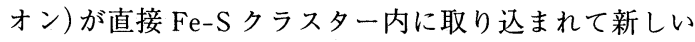
クラスターを形成しているものであり, 他は活性部位の 金属イオンが Fe-S クラスター近傍に存在し, リガンド を介して磁気的に相互作用しているものである。後者の 複合錯体間に見出されている磁気的相互作用は多電子移 動を伴う反応サイトにとって不可欠と考えられるが, 現 状ではその役割は明確でない。

ここでは金属醳素の活性部位の研究を通して判明して

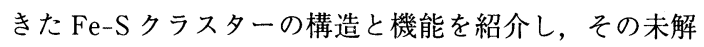
決問題に対するモデル錯体の寄与, および機能モデル合 成の現状について紹介する。

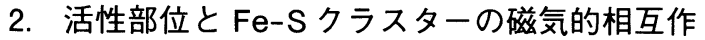 用(磁気機能)}

金属蛋白質・酵素には 1 個の蛋白質中に複数個の金 属イオンを含み，(1)それぞれの間に磁気的相互作用が観 測されるもの，(2)金属イオンを含む各々のサブユニット

$*$ 大阪大学理学部高分子学科

* Department of Maoromolecular Science, Faculty of Sciencc, Osaka University,
が会合し，各々の金属イオンの間に独特の磁気的相互作

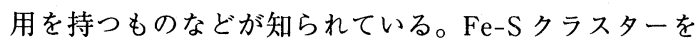
含むものに限れば, $2 \mathrm{Fe}$ 型， $3 \mathrm{Fe}$ 型， $4 \mathrm{Fe}$ 型， $8 \mathrm{Fe}$ 型 フェレドキシン，ヒドロゲナーゼ，キサンチンオキシダ 一ゼなどがこれにあたり，図1にこれらの金属蛋白質・ 䣲素の構造と金属イオン間の磁気的相互作用を示した。 反強磁性のものが多いが, 強磁性もみられ, 電子伝達の 機能と磁気的相互作用は深いかかわりを持つと思われ る。またこれらの磁気機能を手本として，より簡単なモ デル錯体を合成し，それらの機能を利用する試みがはじ まりつつある。

\section{3. 鉄硫黄クラスターの電子伝達機能}

上記の金属蛋白質・醳素の $\mathrm{Fe}-\mathrm{S}$ クラスターは生体膜 中の電子伝達系における $\mathrm{Fe}-\mathrm{S}$ クラスターの機能と同じ く, 速い電子伝達を行っていると考えられている。疎水 的環境下, 2 個の金属イオン間の効率の良い電子伝達 (速 度のみならず逆反応を抑える効率を含む)のためには， 適当な酸化還元電位を持つ $\mathrm{Fe}-\mathrm{S}$ クラスターでつながれ なければならない。従って, 酸化還元電位の調節の必要 性があるが，簡単なチオラート配位子による調節では限 界があることから，天然の蛋白質でペプチド配位子がど のように調節しているかを知る必要がある。

〔4 Fe-4 S \クラスターを持つ錯体は下のような酸化状 態を取り得るはずであるが, Holm らによって数多く合 成されてきたアルキルまたはアリールチオラートのモデ ル錯体では，準可逆的な (3-/2-)酸化還元系だけを持っ ている8)。

また, C. pasteurianum やD. desulfuricans などのフェ レドキシンでもこの 3-/2-酸化還元系を使うが, 電位は 表 1 に示すように正方向にシフトしていて，NADPH(生 


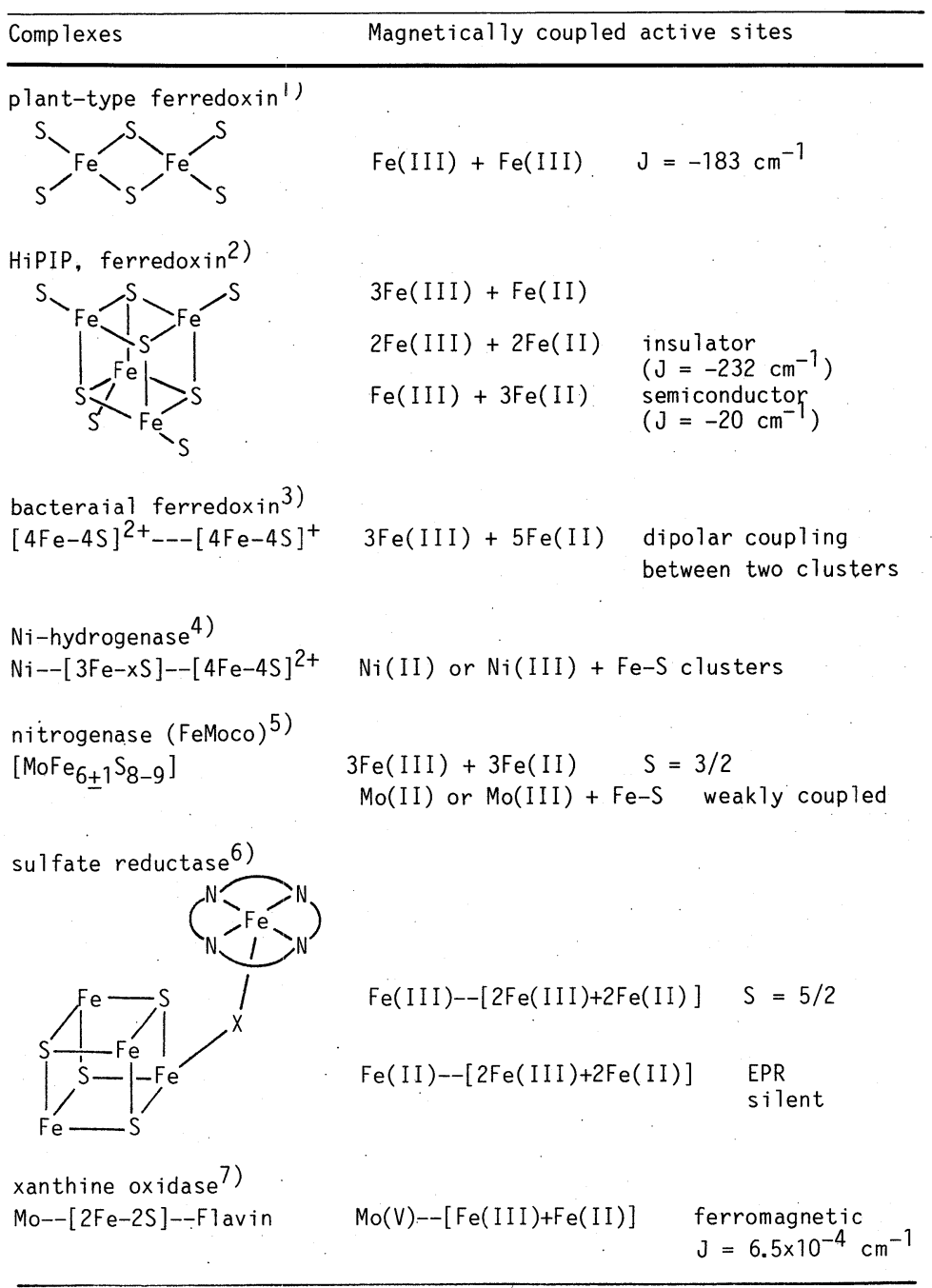

Fig. 1 Magnetically coupled active site of metalloprotein and metalloenzyme.

$$
\begin{aligned}
& {\left[\mathrm{Fe}_{4} \mathrm{~S}_{4}(\mathrm{SR})_{4}\right]^{1-} \underset{-\mathrm{e}^{-}}{\stackrel{\mathrm{e}^{-}}{\rightleftharpoons}}\left[\mathrm{Fe}_{4} \mathrm{~S}_{4}(\mathrm{SR})_{4}\right]^{2-}} \\
& \underset{-\mathrm{e}^{-}}{\stackrel{\mathrm{e}^{-}}{\rightleftharpoons}}\left[\mathrm{Fe}_{4} \mathrm{~S}_{4}(\mathrm{SR})_{4}\right]^{3-}
\end{aligned}
$$

体系での還元剤)による還元が可能な範囲にある ${ }^{9)}$ 。こ れらの酸化還元電位は溶媒の誘電率 9,10$)$, あるいは $\mathrm{pH}$ の影響を受けるが，蛋白質内ではぺプチド鎖による直接 の配位原子 (無機硫黄, $\mathrm{S}^{2-}$ および有機硫黄 $-\mathrm{SCH}_{2}-$ ) 以外の相互作用をも受けている。著者らは細菌型フェレ ドキシンの囲りの不変性アミノ酸配列が錯体化学的な性 質を決める役割を行うと考え，この配列の部分部分を含 むオリゴペプチド・モデル錯体を合成しだ。例えば細菌
型フェレドキシンの不変性アミノ酸を含む部分配列 Cys-Gly-Ala を持つ $\left[\mathrm{Fe}_{4} \mathrm{~S}_{4} \text { (Z-cys-Gly-Ala-OMe) }{ }_{4}\right]^{2-}$ $(Z=$ ベンゾキシカルボニル) 合成し, その酸化還元電位 を調べた。N.N-ジメチルホルムアミド (DMF) などの極 性溶媒中では, 温度を変化させても酸化還元電位は殆ん ど変化しないが, ジクロロメタンなどの極性の弱い溶媒 中では低温で電位は $0.15 \mathrm{~V}$ 程度正方向へシフトする。 これは踈水性環境下で $\mathrm{NH} \cdots \mathrm{S}$ 水素絬合がより安定化す るためであり，これが $[4 \mathrm{Fe}-4 \mathrm{~S}]$ クラスターの性質を変 化させ電位をシフトさせることがわかった (図 2) ${ }^{13)}$ 。 この水素結合の存在は P.aerogenes フェレドキシンの $\mathrm{X}$ 線結晶構造解析から推定されていたが, ペプチドモデル 
Table 1 Redox potentials $(3-/ 2-)$ of $[4 \mathrm{Fe}-4 \mathrm{~S}]$ ferredoxin model complexes ${ }^{9,13-15)}$ and proteins ${ }^{9)}$.

\begin{tabular}{|c|c|c|}
\hline Complexes & Solvents & $\begin{array}{l}\text { Redox potentials } \\
\text { (V vs. SCE) }\end{array}$ \\
\hline C. pasteurianum & $\mathrm{Me}_{2} \mathrm{SO}$ & -0.93 \\
\hline$(2 \times[4 \mathrm{Fe}-4 \mathrm{~S}])$ & $\mathrm{H}_{2} \mathrm{O}$ & -0.67 \\
\hline D. desulfuricans & $\mathrm{H}_{2} \mathrm{O}$ & -0.57 \\
\hline$\left[\mathrm{Fe}_{4} \mathrm{~S}_{4}(\mathrm{SEt})_{4}\right]^{2-}$ & $80 \% \mathrm{Me}_{2} \mathrm{SO} / \mathrm{H}_{2} \mathrm{O}$ & -1.33 \\
\hline \multirow[t]{2}{*}[\mathrm{Fe}_{4}\mathrm{S}_{4}(\mathrm{SCH}_{2}\mathrm{CH}_{2}\mathrm{OH})_{4}]{$^{2-}$} & $80 \% \mathrm{Me}_{2} \mathrm{SO} / \mathrm{H}_{2} \mathrm{O}$ & -1.17 \\
\hline & $\mathrm{H}_{2} \mathrm{O}$ & -0.75 \\
\hline \multirow[t]{2}{*}[\mathrm{Fe}_{4}\mathrm{S}_{4}(\mathrm{Ac}-\mathrm{cys}-\mathrm{NHCH}_{3})_{4}]{$^{2-}$} & $80 \% \mathrm{Me}_{2} \mathrm{SO} / \mathrm{H}_{2} \mathrm{O}$ & -0.98 \\
\hline & $\mathrm{H}_{2} \mathrm{O}$ & -0.73 \\
\hline \multirow[t]{3}{*}[\mathrm{Fe}_{4}\mathrm{S}_{4}(\mathrm{Z}\text{-cys-Gly-Ala-OMe})_{4}]{$^{2-}$} & DMF & -0.97 \\
\hline & $\mathrm{CH}_{2} \mathrm{Cl}_{2}\left(30^{\circ} \mathrm{C}\right)$ & -0.93 \\
\hline & $\mathrm{CH}_{2} \mathrm{Cl}_{2}\left(-40^{\circ} \mathrm{C}\right)$ & -0.85 \\
\hline \multirow[t]{3}{*}[\mathrm{Fe}_{4}\mathrm{S}_{4}(\mathrm{Z}\text{-cys-Gly-Ala-cys-OMe})_{2}]{$^{2-}$} & DMF & -0.94 \\
\hline & $\mathrm{CH}_{2} \mathrm{Cl}_{2}\left(30^{\circ} \mathrm{C}\right)$ & -0.91 \\
\hline & $\mathrm{CH}_{2} \mathrm{Cl}_{2}\left(-40^{\circ} \mathrm{C}\right)$ & -0.85 \\
\hline \multirow[t]{2}{*}[\mathrm{Fe}_{4}\mathrm{S}_{4}(\mathrm{Z}\text{-cys-Ile-Ala-cys-Gly-Ala-cys-OMe})(\mathrm{S}-t-\mathrm{Bu})]{$^{2-}$} & DMF & -0.80 \\
\hline & $\mathrm{CH}_{2} \mathrm{Cl}_{2}\left(30^{\circ} \mathrm{C}\right)$ & -0.78 \\
\hline
\end{tabular}

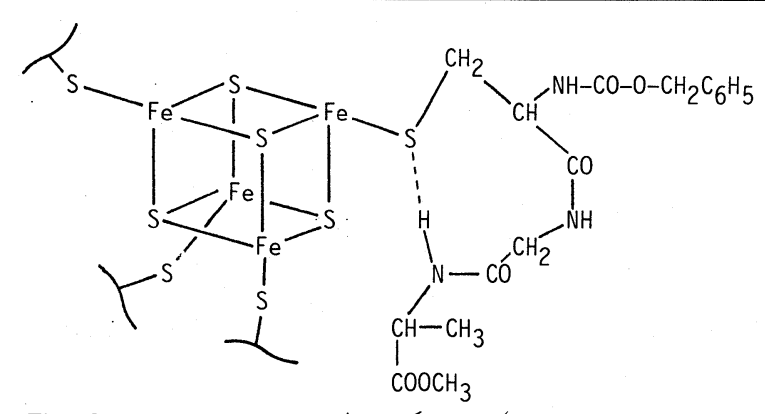

Fig. 2 Proposed structure of $\mathrm{CFe}_{4} \mathrm{~S}_{4}$ (Z-cys-Gly-Ala$\mathrm{OMe})_{4}$ having $\mathrm{NH} \cdots$ Shydrogen bonds.

錯体の合成によりその役割が明らかになった。またモデ ル錯体 $\left[\mathrm{Fe}_{4} \mathrm{~S}_{4}(\mathrm{Z} \text {-cys-Gly-Ala-cys-OMe })_{2}\right]^{2-}$ の合成に よって, 不変性アミノ酸配列 Cys-X-Y-Cys $の \mathrm{Fe}_{4} \mathrm{~S}_{4}{ }^{2+}$ 核へのキレート配位で $\mathrm{Y}$ 残基の $\mathrm{NH}$ が前にある Cys 残 基の $\mathrm{S}$ 原子に近づき, $\mathrm{NH} \cdots \mathrm{S}$ 水素結合方強制的に形成 されることが判った ${ }^{14)}$ 。一方, P. aerogenes フェレドキ シンの 2 個の $[4 \mathrm{Fe}-4 \mathrm{~S}]$ クラスターの一方のクラスター の中心から $5 \AA$ 以内人にあ不変性アミノ酸残基を含む錯 体 $\left[\mathrm{Fe}_{4} \mathrm{~S}_{4}\right.$ (Z-cys-Ile-Ala-cys-Gly-Ala-cys-OMe) (S- $t$ $\mathrm{Bu})]^{2-}$ ではその酸化還元電位が極性の DMF 中.で $-0.80 \mathrm{~V}(\mathrm{SCE})$ であり, 非極性の塩化メチレン中のー 0.78 $\mathrm{V}(\mathrm{SCE})$ と同じように正側にシフトしている15)。これは 〔4 Fe-4 S〕クラスターの囲りの第一層のアミノ酸残基に よりすでに溶媒からの遮蔽が充分に行われていることを
示す。また，天然のフェレドキシンの電気化学的性質が 主にこの第一層のアミノ酸残基によって決定されている ことを示唆している。

通常のフェレドキシンでは観測されない $(2-/ 1-)$ 酸化 還元系を使って電子伝達を行う高電位鉄硫黄蛋白質 $(\mathrm{Hi}$ PIP) は同じ [4 Fe-4 S]クラスターを持っているにもかか わらず (3-/2-)の酸化還元系を示さない16)。この特異な 性質の要因は著者らのペプチドモデルの研究から, Cys チオラート配位子の回りの立体障害によることが判明し た ${ }^{17)}$ 。例えば，モデル錯体 $\left[\mathrm{Fe}_{4} \mathrm{~S}_{4}\right.$ (Z- cys- Ile- Ala$\left.\mathrm{OMe})_{4}\right]^{2-},\left[\mathrm{Fe}_{4} \mathrm{~S}_{4}(\mathrm{Z} \text {-cys-Pro-Leu-OMe })_{4}\right]^{2-}$ 合成し て，CV を測定すると 2-/1-の酸化還元系が著しく安定 化する。実際，嵩高いチオラート錯体， $\left[\mathrm{Fe}_{4} \mathrm{~S}_{4}(2,4,6\right.$ トリメチルアルキルベンゼンチオラート) $\left.{ }_{4}\right]^{2-}$ の CV で はS の囲りの立体障害だけで (1-) 状態が安定化す る $^{17,18)}$ 。この中で $\left[\mathrm{Fe}_{4} \mathrm{~S}_{4}(2,4,6\right.$-トリメチルベンゼン チオラート) $\left.{ }_{4}\right]^{2-}$.の結晶構造を調べたところ, S の $\mathrm{p} \pi$ と $\mathrm{Fe}$ との $\pi$ 結合性が弱くなり, Fe-S-C の角は狭くなっ ていることから, $\mathrm{Fe}-\mathrm{S}(\mathrm{C})$ のイオン結合性が増したため, 高酸化状態 (1-状態, $3 \mathrm{Fe}($ III $)+\mathrm{Fe}(\mathrm{II}))$ が安定化した と考えた ${ }^{19)}$ 。このように[4 Fe-4 S]クラスターは Fe-S (C) の距離抒よび torsion 角が変化することによりクラ スターの性質が著しく変化する。これは鉄硫黄蛋白質の 配位子であるぺプチド鎖のコンホメーション変化で $\mathrm{Fe}$ $\mathrm{S}(\mathrm{C})$ の距離および Fe-S-C 角が変化し, 機能制御が行わ 
れることを示していて興味深い。

\section{4.〔4 Fe-4 S〕クラスターを活性部位に持つ金属 酵素とモデル錯体}

アコニターゼは広く動植物の細胞内に存在する重要な 酵素であり，次の反応を行う。<smiles>O=C([O-])C(O)C(C(=O)[O-])C(=O)CO</smiles>

citrate<smiles>C=CC(C(=O)[O-])C(=O)[O-]</smiles>

cis-aconitate<smiles>O=C([O-])C(O)C(C(=O)[O-])C(=O)[O-]</smiles>

iso-citrate
一旦単離すると，この酵素の再活性化には $\mathrm{Fe}$ ( II ) イ オンの添加を要することから，長い間単核の $\mathrm{Fe}$ (II) が

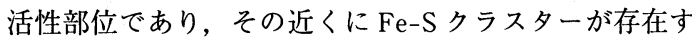
ると考えられてきた ${ }^{20)}$ 。最近になって，活性部位は [4 Fe-4 S]クラスター自身であるが，単離操作の途中で 〔3 Fe-4 S〕に变換することが判明した ${ }^{21)}$ 。図3に示すよ

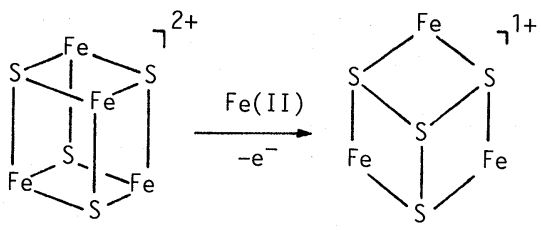

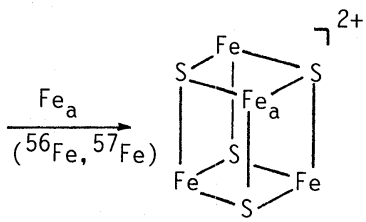

Fig. 3 Interconversion between $[4 \mathrm{Fe}-4 \mathrm{~S}]$ and $[3 \mathrm{Fe}-4 \mathrm{~S}]$.

うに $[4 \mathrm{Fe}-4 \mathrm{~S}]$ 核の中の 1 個は脱離し易いために, 実験 操作中に $3 \mathrm{Fe}$ クラスターになっていたのである。この タイプの変換は細菌型フェレドキシンでも見出されてい る ${ }^{22)}$ 。この脱離し易い $\mathrm{Fe}_{\mathrm{a}}$ に同位体 ${ }^{56} \mathrm{Fe},{ }^{57} \mathrm{Fe}$ を導入 した。〔3 $\left.\mathrm{FeFe}_{\mathrm{a}}-4 \mathrm{~S}\right]$ を持つアコニターゼが合成され(図 3）,メスバワースペクトルで解析された。その結果, 基質であるクエン酸は $\mathrm{Fe}_{\mathrm{a}}$ とのみ反応し,他の [3 Fe-4 S] ユニットとは反応しないことが判明した ${ }^{23)}$ 。

このように $[4 \mathrm{Fe}-4 \mathrm{~S}]$ クラスター自体が酵素の活性部 位であるということは, 従来単核 $\mathrm{Fe}$ (II ) とその近傍に 存在する $\mathrm{Fe}-\mathrm{S}$ クスターの協同作用と考えられている 多くの金属酵素についても同じような構造になっている 可能性がある。また上に述べたように活性部位と Fe-S クラスターが一つになった複合クラスターを形成し, 錯
体化学でみられる均一なクラスター化学とは異った特異 な挙動で酵素作用が支えられていることを示している。 この不均一な $[4 \mathrm{Fe}-4 \mathrm{~S}]$ クラスターの形成は特徴あるア ミノ酸配列を持つペプチド配位子に起因するのであろ う。

$\mathrm{Fe}-\mathrm{S}$ クラスターを活性部位に持つと考えられている ものにフマレート・レダクターゼとコハク酸デヒドロゲ ナーゼがあり，これらが触媒する反応を下に示した。

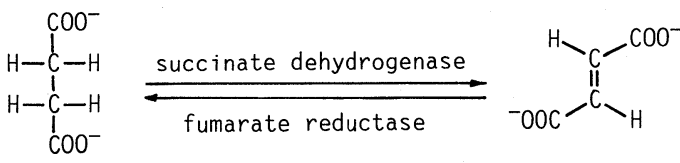

succinate

fumarate

フマレート・レダクターゼは 2 個の蛋白質 $(\mathrm{A}, \mathrm{B})$ か らなり，A は 4 個のサブユニットで構成され，B は 2 個のサブユニットからなる。A は共有結合した FADを 持つサブユニット $\left(\mathrm{M}_{\mathrm{r}}=6.6\right.$ 万 $)$ および鉄硫黄蛋白質 $\left(\mathrm{M}_{\mathrm{r}}\right.$ $=2.7$ 万) からなり, $\mathrm{B}$ 部分は細胞膜への接合部として 働いている ${ }^{24)}$ 。MCD および EPR スペクトルの研究か $ら[3 \mathrm{Fe}-\mathrm{xS}] /[2 \mathrm{Fe}-2 \mathrm{~S}] /[4 \mathrm{Fe}-4 \mathrm{~S}] /[\mathrm{FAD}]$ が$(1: 1: 1$ : 1)の組成を持つと考えられている ${ }^{25)}$ 。またコハク酸 デヒドロゲナーゼは上の式のようにフマレート・レダク ターゼの逆反応を行う酵素で，同じょうにFAD 蛋白質 $\left(\mathrm{M}_{\mathrm{r}}=7\right.$ 万) と $\mathrm{Fe}-\mathrm{S}$ クラスターを含む蛋白質 $\left(\mathrm{M}_{\mathrm{r}}=2.7\right.$ 万) からなる ${ }^{26)}$ 。従って, この酵素の構造は上記のフマ レート・レダクターゼに似たものと推定できる。またコ ハク酸からの脱水素反応は多電子移動とカップルしたプ ロトン移動によって行われている。この両者を同時に行 うのが Fe-S クラスターの特徴である。

\section{5. ヒドロナーゼとそのモデル錯体および関連モ デル反応}

ヒドロゲナーゼは下記のように分子状水素を可逆的に 酸化し，電子を取り出す反応を行う酵素であるが，その 反応および性質については既に詳細な総説があるので参 照してほしい27,28)。

$$
\mathrm{H}_{2} \longrightarrow 2 \mathrm{H}^{+}+2 \mathrm{e}^{-}
$$

この酵素の中には $\mathrm{Ni}$ を活性部位に含むもの (後述)も あるが，活性部位が Fe-S クラスターであるとされてい るものも多い。例えば C.pasteurianum $\left(\mathrm{M}_{\mathrm{w}}=6\right.$ 万)や Megasphaera elsdenii から得られる[12 Fe-12 S ヒドロゲ ナーゼはこの Fe-S クラスターのみからなる。チオフェ ノールによる core extrusion で $[4 \mathrm{Fe}-4 \mathrm{~S}]$ のみが得られ 
ることから， 3 個の $[4 \mathrm{Fe}-4 \mathrm{~S}]$ クラスターを持つと考え られている。これらの $[4 \mathrm{Fe}-4 \mathrm{~S}]$ クラスター間は独特の 磁気的相互作用を持つことが EPR スペクトルより観測 されている29)。

〔4 Fe-4 S〕モデル錯体による触媒作用の研究は通常の 〔4 Fe-4 S 錯体が持つ比較的安定な 3-/2-酸化還元系を 使って行われてきた。例えば井上らは下記の反応を $n$ ブチルリチウムを還元郕にして $\left[\mathrm{Fe}_{4} \mathrm{~S}_{4}(\mathrm{SPh})_{4}\right]^{2-}$ の存在 下で行い，チオフェノールを補給すれば触媒的にも進む ことを見出している30)。

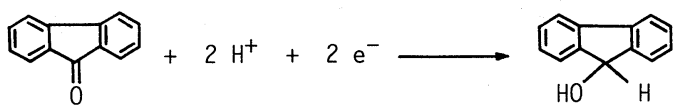

また $\left[\mathrm{Fe}_{4} \mathrm{~S}_{4} \mathrm{Cl}_{4}\right]^{2-} / n$-ブチルリチウム $/ \mathrm{H}_{2}$ 系で cis-ス チルベン, trans-スチルベン, ジフェニルアセチレンの 還元を ${ }^{31)}$ ，また同じ系でケトン ${ }^{32)}$, エステルの還元 ${ }^{33)}$ を行い, 対応する水素添加化合物を得ている。また中村 らは $\mathrm{NaBH}_{4}$ を還元鼡にして $\left[\mathrm{Fe}_{4} \mathrm{~S}_{4}(\mathrm{SPh})_{4}\right]^{2-}$ 存在下, 触媒的にアゾベンゼン，フェニルアセチレンを還元する 反応を見出している ${ }^{34)}$ 。還元型 $[4 \mathrm{Fe}-4 \mathrm{~S}]$ クラスター である $\left[\mathrm{Fe}_{4} \mathrm{~S}_{4}(\mathrm{SPh})_{4}\right]^{3-}$ とアセチレンとの反応にプロト ン源として酥酸/無水酥酸を添加するとエチレンが化学 量論的に生成する ${ }^{35)}$ 。電気化学的に還元した(3-) ある いは(4-)によってイソニトリルやニトリルの還元が行 われている ${ }^{36)}$ 。 $\left[\mathrm{Fe}_{4} \mathrm{~S}_{4}\left(\mathrm{SCH}_{2} \mathrm{Ph}\right)_{4}\right]^{2-}$ を電気化学的に還 元したとき, 二酸化炭素からギ酸と安息香酸を与えるこ とが見出されている ${ }^{37) 。 ~}$

ヒドロゲナーゼの反応を合成 $[4 \mathrm{Fe}-4 \mathrm{~S}]$ 錯体を用いて 行った研究も多く報告されている。大倉らは還元したア ルブミンの $[4 \mathrm{Fe}-4 \mathrm{~S}]$ 錯体がジチオナート存在下で触媒 的に水素を発生することを見出した ${ }^{38)}$ 。また Holm らは $\left[\mathrm{Fe}_{4} \mathrm{~S}_{4}(\mathrm{SPh})_{4}\right]^{3-}$ がチオフェノール存在下 $30 \%$ 程度の 水素を発生することを報告している ${ }^{39)}$ 。 $[4 \mathrm{Fe}-4 \mathrm{~S}]$ ク ラスターがプロトンと電子によりヒドリド中間体とな り，水素を生成する機構が議論されている。

このように単純なモデル錯体でも一部反応が起ること から, 合成ヒドロゲナーゼの実現の可能性は高いと思わ れる。

また，へム鉄， $\mathrm{Cu}$ 蛋白質と同様，フェレドキシンに も膜中の役割として知られているプロトン輸送がモデル 錯体を用いて報告されている。Sweeney らは $\left[\mathrm{Fe}_{4} \mathrm{~S}_{4}\right.$ $\left.(\mathrm{SPh})_{4}\right]^{2-}$ を使い, トルエン/水系で $\mathrm{Cr}(\mathrm{II})$ からメチル ビオローゲンへの電子伝達と同時にプロトンの輸送も起 ることを示した ${ }^{40)}$ 。

これらの (3-/2-)酸化還元系を使うモデル反応に対し
て，著者らは $[4 \mathrm{Fe}-4 \mathrm{~S}]$ 錯体の (2-/1-)酸化還元系を使 うモデル反応を調べた。前に述べたようにチオラート配 位子の立体効果により (2-/1-)酸化還元が可逆になるこ とが判ったが, (2-)がベンゾキノンによって容易に （1-）になることから，図 4 のような酸化還元触媒反応

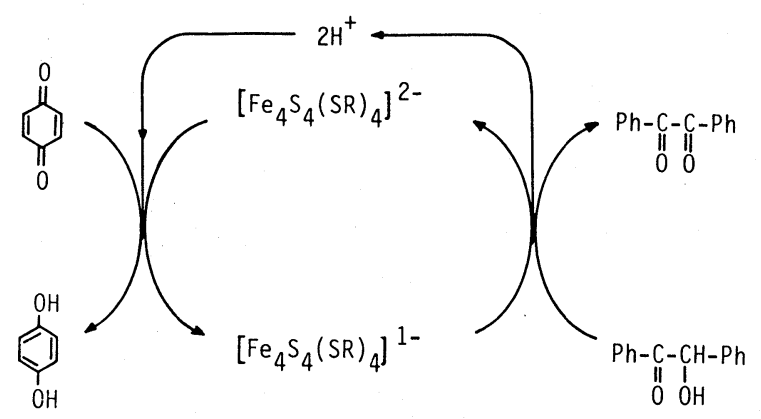

Fig. 4 Catalytic oxidation of benzoin by benzoquinone in the presence of $[4 \mathrm{Fe}-4 \mathrm{~S}]$ cluster.

を調べた ${ }^{41)}$ 。ベンゾインは脱水素反応でベンジルにな り，そのとき放出するプロトンと電子は $[4 \mathrm{Fe}-4 \mathrm{~S}]$ クラ スターを通してベンゾキノンに移動する。この触媒反応 は嵩高いチオラート配位子を持つ $[4 \mathrm{Fe}-4 \mathrm{~S}]$ 錯体が存在 すると高能率で触媒的に進むことが判った。前に述べた (3-/2-) 酸化還元系を使って主に有機基質の還元を行う モデル反応に比べ，この(2-/1-)酸化還元を使った触媒 反応では，そのターンオーバー数が著しく大きい。これ は通常の合成 $[4 \mathrm{Fe}-4 \mathrm{~S}]$ 錯体が非可逆的な (2-/1-) 酸化 還元系を零 V $\mathrm{SCE})$ 付近に持つために，(3-/2-)酸化還 元系だけを使うことを目的としたモデル反応系でも，触 媒サイクルの酸化過程で (3-) から (2-) 更に(1-)にまで 反応が進んでしまうことによる。(1-)状態は通常の合 成 [4 Fe-4 S]錯体では著しく不安定 (2-/1-が非可逆的) なために(3-/2-) 酸化還元系を使う触媒反応の夕ーンオ 一バー数は余り大きくならないと考える。

\section{Ni を含む鉄硫黄蛋白質}

最近になってヒドロゲナーゼの中に $\mathrm{Ni}$ を含むものが あるとわかり, 盛んに研究が行われている。例えばDesulfovibrio gigas から抽出されたヒドロゲナーゼは Niを 含み, 〔3 Fe-xS]クラスター, [4 Fe-4 S クラスターを 1 個づつ含む酵素 $\left(\mathrm{M}_{\mathrm{r}}=8.9\right.$ 万)である ${ }^{42)}$ 。初期段階で分 子状酸素が存在するとき $\mathrm{Ni}($ III $)$ の $\mathrm{EPR}$ シグナルが見ら れ， Fe-S クラスターも高酸化状態にあり，酸素が除去 されると $\mathrm{EPR}$ 不活性な 3 の状態になり，その時醳素活 性を示す(図 5)。この場合, 分子状水素が存在するとイ オン開裂によりヒドリド中間体を経て反応すると推定さ 


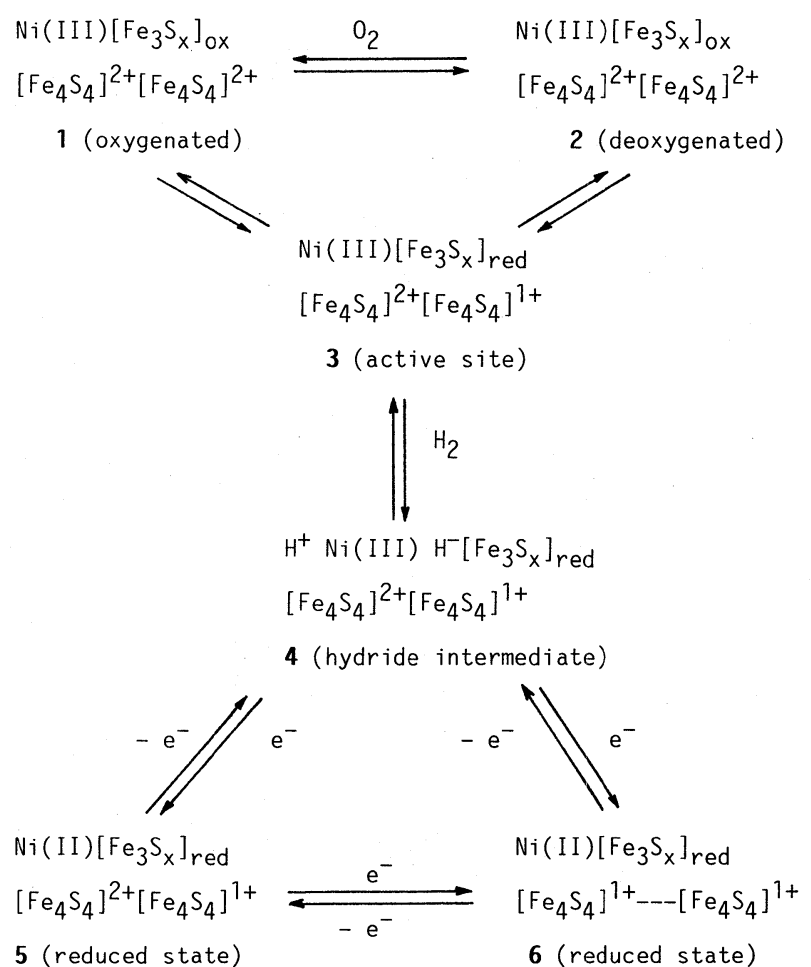

Fig. 5 Oxidation states of the active site of $\mathrm{Ni}$-hyd rogenase.

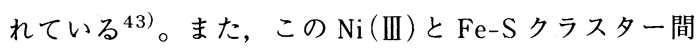
の磁気的相互作用が EPR スペクトルで確認されている。

C.thermoacetium からの一酸化炭素デヒドロゲナーゼは $\mathrm{Zn} / \mathrm{Ni} / \mathrm{Fe} / \mathrm{S}^{2-}$ が $(1: 2: 11: 14)$ の組成で補欠分子族 を含み, サブユニット 2 個からなる酵素 $\left(\mathrm{M}_{\mathrm{r}}=15\right.$ 万) で

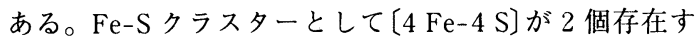
ると考えられている。反応は次の様に進み, $\mathrm{CO}$ からの 電子によりメチルビオローゲンを還元する能力を持 $\supset^{44)}$ 。

$\mathrm{CO}+\mathrm{H}_{2} \mathrm{O} \longrightarrow \mathrm{CO}_{2}+2 \mathrm{e}^{-}+2 \mathrm{H}^{+}$

この酵素は反応の中間に $\mathrm{Ni}(\mathrm{III})-\mathrm{C}$ 結合を形成するこ とが EPR 測定によって推定されている。この $\mathrm{Fe}, \mathrm{Ni}$, $\mathrm{C}$ は互いにスピン相互作用し, 全体で $\mathrm{S}=1 / 2$ 系となっ ている ${ }^{45)}$ 。Saccoらは図のようなソフトなキレート状フ

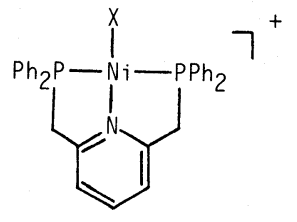

$(\mathrm{X}=\mathrm{Cl}, \mathrm{Br})$
オスフィン配位子を持つ錯体が water gas shift 反応を $40^{\circ} \mathrm{C}$ 付近で行うことを見出していることから ${ }^{46)}, \mathrm{Ni}$ 酵 素の活性中心は硫黄配位子などソフトな配位子を持つ $\mathrm{Ni}$ (II) と推定されている。

\section{Mo を含む鉄硫黄酵素とそのモデル錯体およ びモデル反応}

このタイプの中で空中窒素固定を行うニトロゲナーゼ のモデル錯体については多くの総説があるので47), 最 近の動向について紹介する。ニトロゲナーゼは $\mathrm{MoFe}$ 蛋 白質と $\mathrm{Fe}-\mathrm{S}$ 蛋白質が各々 2 個づつ, 計 4 個のサブユニ ットからなる酵素である。この MoFe 蛋白質をクエン酸 処理することによって活性部位として FeMo コファクタ 一(FeMoco) が抽出できる。このコファクターは $\mathrm{MoFe}_{7 \pm 1} \mathrm{~S}_{8 \sim 9}$ の組成を持ち, $N$-メチルホルムアミド (NMF)に溶ける。しかし, DMF には溶けない年)。Mo がFe-Sクラスターに取り込まれていることは, FeMoco が分子状酸素と反応するとき Mo-S-Fe がまず切れて, $\left[\mathrm{MoOS}_{3}\right]^{2-}$ を元, $\mathrm{Cu}\left(\mathrm{PPh}_{3}\right)_{2} \mathrm{NO}_{3}$ 添加によって $[\mathrm{MoO}$ $\left(\mathrm{CuPPh}_{3}\right)_{3} \mathrm{~S}_{3} \mathrm{Br}$ ] の赤色結晶としてトラップされること から確認された ${ }^{49)}$ 。また EXAFSの結果からMoの囲り に2 4 個の $\mathrm{S}^{2-}, 1 \sim 3$ 個の $\mathrm{Fe}$ が結合距離内に存在す るとされ ${ }^{50)}$, 図 6 のようなクラスター構造が推定され
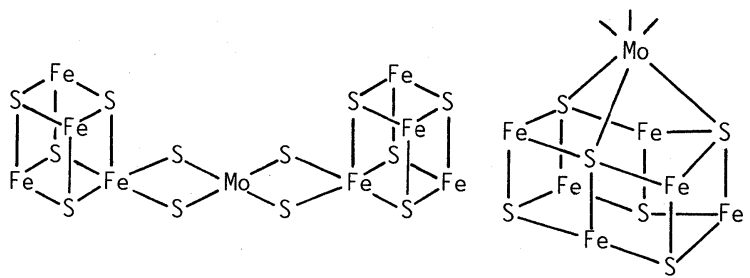

Fig. 6 Two proposed structures of FeMoco. ている。このコファクターは MoFe 蛋白質から容易に脱 離してくることから, 全体としては大きなカチオン錯体 であるにもかかわらず，ペプチド配位子を持たないと考 えられていた。最近，このコファクターが環状アミドで ある2-ピロリジノンにも可溶であることが判り, FeMoco は cis-アミドの脱プロトン化した配位子を持つ 錯体 ( (RCONR $\left.)_{n} M\right)$ と推定されている ${ }^{51)}$ 。従ってアミノ 酸側鎖部分に存在する非常に脱離し易いアニオン配位子 にこのコファクターは結合していると考えられる。 ${ }^{33} \mathrm{~S}$ を導入したC. pasteurianum ニトロゲナーゼを使った ENDOR 測定では, ${ }^{33} \mathrm{~S}$ は無機硫黄としてのみ観測され る。従って上記のコファクターのためのアミノ酸配位子 はCys チオラート(有機硫黄)ではないと提唱されてい $3^{52)}$ 。 
一方, MoFe 蛋白質の酸化還元電位が直接法ではなく, メチルビオローゲンを媒体にして測定されている。この 蛋白質の電位は $-0.17 \mathrm{~V}$ とー0.65 V (NHE)であり, FeMoco は NMF 中でー $0.3 \mathrm{~V}$ とー1.1 V (NHE)である。 溶媒の誘電率を考慮しても, 電位差が蛋白質とコファク ターの間で大きいことから，クラスターを取り囲むぺプ チド鎖からの電位を変化させるような相互作用が存在す るのであろう ${ }^{53)}$ 。

現在, FeMoco のモデル錯体の合成が盛んに行われて いる。これは $\mathrm{MoFe}$ 蛋白質の EXAFS の結果をもとにし て, Mo, Fe, S $\mathrm{S}^{2-}$ を含むクラスター錯体を合成し, 錯 体化学的に研究するアプローチである。〔Fe (Mo $\left.\left.\mathrm{S}_{4}\right)_{2}\right]^{3-54)},\left[\mathrm{Mo}_{2} \mathrm{Fe}_{6} \mathrm{~S}_{8}(\mathrm{SPh})_{9}\right]^{3-55)}$, は NMF 中で分 解することから FeMoco に近いとは考えられない。〔Mo $\left.\left.\mathrm{S}_{4}\right]^{2-56)}, \quad\left[\mathrm{X}_{2} \mathrm{FeMo} \mathrm{S}_{4}\right]^{2-}(\mathrm{X}=\mathrm{PhS}, \mathrm{Cl})^{57}\right), \quad\left[\left(\mathrm{Cl}_{2}\right.\right.$ $\left.\mathrm{Fe})_{2} \mathrm{MoS}_{4}\right]^{2-58)},\left[\mathrm{Fe}\left(\mathrm{MoS}_{4}\right)_{2}\right]^{3-59)}$ は $\mathrm{FeMo}$ 蛋白質と よく似た EXAFS スペクトルを示す。一方 Mo-XAS スペ クトルでは, $\left[\mathrm{Mo}_{2} \mathrm{Fe}_{6} \mathrm{~S}_{8}(\mathrm{SEt})_{9}\right]^{3-},\left[\mathrm{Mo}_{2} \mathrm{Fe}_{7} \mathrm{~S}_{8}\right.$ $\left.(\mathrm{SEt})_{12}\right]^{3-60)},\left[\mathrm{Mo}\left(\mathrm{S}_{2} \mathrm{C}_{6} \mathrm{H}_{4}\right)_{3}\right]^{61)}$ は FeMo 蛋白質と異 なるが, $\mathrm{MoS}_{3} \mathrm{O}_{3}$ 型錯体の $\left[\mathrm{MoFe}_{3} \mathrm{~S}_{4}(\mathrm{SEt})_{3} \mathrm{Fe}(\mathrm{cat})_{3}\right]^{3-}$ $(\text { cat = カテコラート })^{62)}$ や $\left(\mathrm{Mo}_{2} \mathrm{Fe}_{6} \mathrm{~S}_{8} \quad(\mathrm{SEt})_{6}\right.$ $\left.(\mathrm{OMe})_{3}\right]^{3-63)}$ は FeMo 蛋白質とよく似た 2.0012 $2.0013 \mathrm{eV}$ に吸収を示す ${ }^{49)}$ 。また最近, [6 Fe-6 S クラ スーの上下に Moを取り込んだ構造を持つ $\left[\mathrm{Mo}_{2}\right.$ $\left(\mathrm{CO}{ }_{6} \mathrm{Fe}_{6} \mathrm{~S}_{6} \mathrm{Cl}_{6}\right.$ ] が合成された ${ }^{64)}$ 。この構造は図 6 の FeMoco の推定構造に近いクラスターといえる。

上に述べた合成錯体を用いて生体系条件に近い場での 窒素分子との反応が各地で調べられてきているが, 反応 活性を示さないこから，いずれの錯体も $\mathrm{MoFe}$ 蛋白質の 活性部位構造とは異なると判断されている。

ニトロゲナーゼの基質となり得る窒素分子，アセチレ ン，ニトリル，アジドなどでモデル錯体を用いた化学シ ミュレーションが研究されている。中でも Schrauzer ら はインシュリン/ $\left[\mathrm{MoO}_{4}\right]^{2-} / \mathrm{NaBH}_{4}$ 系で $2 \mathrm{NH}_{3} / \mathrm{Mo}$ 基準 で115\%収率のアンモニアの生成を報告している ${ }^{65)}$ 。ま た $\mathrm{Mo} / \mathrm{Ti}^{3+} / \mathrm{MgCl}_{2}$ 系で $\mathrm{N}_{2} \mathrm{H}_{2} / \mathrm{Mo}$ 基準でヒドラジドが $200 \%$ 生成したという報告もある ${ }^{66)}$ 。田中らは $\left[\mathrm{Mo}_{2} \mathrm{Fe}_{6} \mathrm{~S}_{8}(\mathrm{SPh})_{9}\right]^{3}$ 一の定電位還元条件で窒素分子から $2 \mathrm{NH}_{3} / \mathrm{Mo}$ 基準で $98 \%$ 収率でアンモニアの生成を確認 しているので67)，今後の収率向上が期待されている。

窒素分子の配位錯体を酸分解することによってアンモ ニアを生成する研究も盛んに行われている。詳しくは総 説を参照して欲しい68)。この反応で分子状窒素 1 分子 から 2 分子のアンモニアが生成せずに 1 分子程度の生 成にとどまることに問題点が残っている。Schrauzerら
は上記の系でわずかではあるが化学量論的反応を越えて いることから，触媒的と主張している。しかし，この系 は再現性に問題があるので, 触媒的に反応が進まない原 因が問題となる。反応機構から考えて，アンモニア生成 は end 型配位の末端 $\mathrm{N}$ から起り，Mo に直結した $\mathrm{N} は$ は安 定な $\mathrm{Mo} \equiv \mathrm{N}$ 錯体になっている可能性がある ${ }^{68,69)}$ 。著 者らは種々のニトリド Mo (VI) 錯体の加水分解, および 還元的加水分解を調べた。その結果, ソフトなチオラー 卜配位子を持つ錯体程，容易にアンモニアを生成するこ とが判った ${ }^{70)}$ 。また，この反応系に合成 $[4 \mathrm{Fe}-4 \mathrm{~S}]$ 錯 体を添加するとアンモニアの生成は増加することか $ら^{71)}$, 生成した混合原子価錯体が多電子を同時に供給 することによって，Mo三N錯体からアンモニア生成反応 が進み易くなったものと考える。

$$
\mathrm{N}_{2}+6 \mathrm{H}^{+}+6 \mathrm{e}^{-} \longrightarrow 3 \mathrm{NH}_{3}
$$

上の反応式のように空中窒素固定のための複雑な多電 子触媒反応においては, Mo 活性部位の背後にある $\mathrm{Fe}-\mathrm{S}$ クラスターの役割が重要である。この分野の研究の進展 によって新しいアンモニア合成触媒など高機能性物質の 開発が可能になるものと思う。

\section{Moを含む酸化酵素とモデル錯体}

Mo を含む酸化酵素として比較的よく研究されている のはキサンチン酸化酵素, アルデヒド酸化酵素, ギ酸酸 化酵素であり，これらはすべて Fe-S クラスターを持つ。 例えばキサンチン酸化酵素は表 1 に示したような磁気 的相互作用が $[\mathrm{Mo}(=0)(=\mathrm{S})], 2 \times[2 \mathrm{Fe}-2 \mathrm{~S}]$, フラビ ンの間で観測されているが, 各々 4 個のサイトの酸化 還元電位は少しづつ異なり, 多電子移動系を形成してい $ろ^{72)}$ 。この酵素の活性部位の構造については, Brayら が蛋白質からチオフェノールで core extrusion L， 2 個 の配位子がチオフェノラートになった Moコファクター (Moco) を得ていることから, 図 7 に近い構造と推定さ

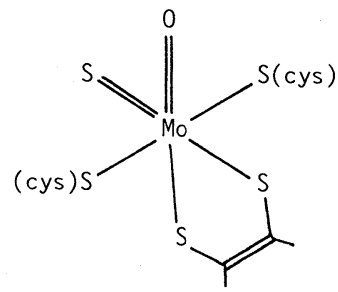

Fig. 7 Proposed active site of xanthine oxidase.

れている73)。また他の 2 個のチオラート配位子は図 8 に示したようなプテリンを持つジチオレン配位子に由来 すると考えられている。この Moco は他の亜硫酸酸化酵 


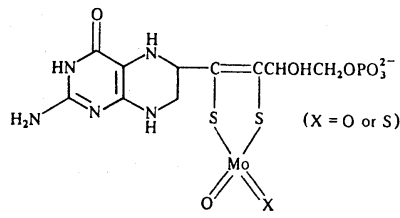

Fig. 8

素，アルデヒド酸化酵素にも同じように活性部位に存在 するといわれ74)，プテリン基が酸化還元反応に関与す る場合には更に複雑な多電子移動系となる。

Mo モデル錯体によるキサンチンの酸化反応は成功し たという報告はないが $\left[\mathrm{Mo}^{\mathrm{V}} \mathrm{O}_{2}\right]$ 種のオキソ移動反応に ついてはトリフェニルフォスフィンを使ってよく調べら れている75)。著者らはこの反応が触媒的に進むために は水の存在が必要であることを見出し, $\left[\mathrm{Mo}^{\mathrm{V}} \mathrm{O}_{2}\right]$ より オキソ移動で生ずる $\left[\mathrm{Mo}^{\mathrm{IV}} \mathrm{O}\right]$ から $\left[\mathrm{Mo}^{\mathrm{V}} \mathrm{O}\right]$ を経る酸素酸 化プロセス(触媒再生)において，この水が $\mathrm{Mo}-\mathrm{OH}$ 結合 を形成して Mo-O-Mo 型となる複核化反応を防ぐ役割を すると考えた ${ }^{76)}$ 。しかし, 実際の酵素では背後に存在 する $[2 \mathrm{Fe}-2 \mathrm{~S}]$ クラスターが動力学的に速い電子伝達 で, しかも多電子的に Mo (N) から Mo (VI) に戻すと推 定している。事実, 図 9 に示すような $\left[\mathrm{MoO}_{2}(\mathrm{cys}-\mathrm{OR})_{2}\right]$

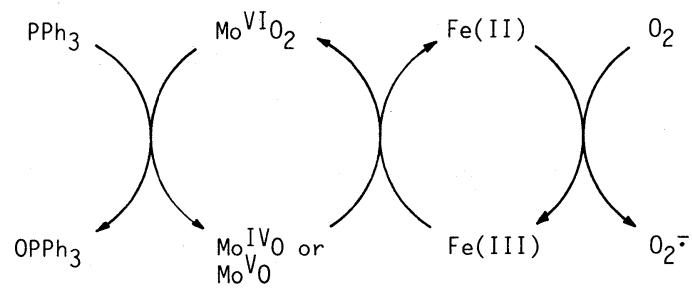

Fig. 9 Catalytic air oxidation of $\mathrm{PPh}_{3}$ in the presence of Mo(VI) complex and hemin.

錯体によるトリフェニルフォスフィンの酸化反応ではへ ミン添加により，著しく触媒反応速度が増す。これは Mo (IV)あるいはMo (V)から Mo (VI)に円滑に戻す役割 をへミンが $\mathrm{Fe}$ (III) / $\mathrm{Fe}$ (II)系を使って行うと考えた ${ }^{77) 。 ~}$

最近, Holm らは図 10 のような 3 座配位子を持つ Mo （VI）錯体を合成し，下のようなオキソ移動反応を行って いる ${ }^{78)}$ 。

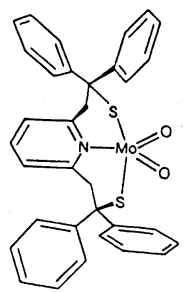

Fig. 10

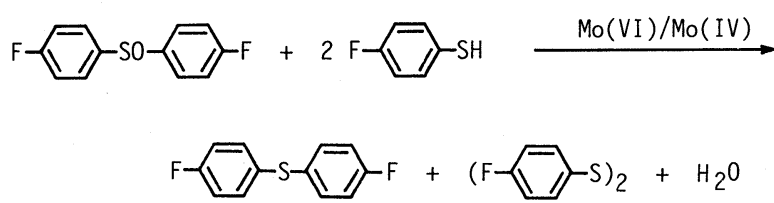

チオールによる $\mathrm{Mo}(\mathrm{VI})$ 錯体の還元反応が遅く, $23^{\circ} \mathrm{C}$, 108 時間でターンオーバー数が 3.8 であると報告されて いる。この錯体は立体障害により Mo (IV) 状態が安定化 し, 原料の $\mathrm{Mo}(\mathrm{VI})$ との不均化反応が起らずに溶媒の DMF が配位している点に特徵がみられる。

著者らは前述のベンゾインが $\left[\mathrm{MoO}_{2}(\mathrm{cys}-\mathrm{OR})_{2}\right]$ 錯体 の存在下で, 空気酸化によりベンジルになることを見出 した ${ }^{79)}$ 。この反応は $\mathrm{C}-\mathrm{H}$ 結合の活性化という点ではキ サンチンの $\mathrm{C}-\mathrm{H}$ への酸素拥入と似ているが, 酸素分子 により水を生成する脱水反応である点が異なる。疎水性 配位子を持つ錯体程, 触媒のターンオーバー数は高く, 例えば $\left[\mathrm{MoO}_{2}\left(\mathrm{cys}-\mathrm{NHC}_{10} \mathrm{H}_{21}\right)_{2}\right]$ では 20 時間, $30^{\circ} \mathrm{C} て ゙$ ターンオーバー数が 18 に達する。酸化力は $(\mathrm{S}, \mathrm{S})$ 配位 子を持つ $\left[\mathrm{MoO}_{2}\left(\mathrm{~S}_{2} \mathrm{CNEt}_{2}\right)_{2}\right]$ がより高いが, 触媒活性の 失活は早いことから, Mo (IV)から Mo (VI)への再酸化過 程で錯体が分解し易いためと考える。

このようにMo 酸化酵素のモデル錯体は一方では酸化 力の向上を目指し, 他方では低原子価状態からの再酸化 過程を円滑に行うための要因の解明に努力が重ねられて いる。しかし, 残念ながら有機反応としても興味深いキ サンチンの酸化は実現されていない。

\section{9. おわりに}

以上のようにニトロゲナーゼのモデル錯体による空中 窒素からアンモニアの合成，あるいはヒドロゲナーゼの モデル錯体によりプロトンと電子から分子状水素の発生 などで, 化学量論量の活性は一部実現されているにもか かわらず，触媒的な反応となると程遠い。これらのモデ ル系では触媒サイクルは成立していないのであるが，天 然の金属醳素では Fe-S クラスターを用いてこのサイク ルを円滑に回していると考えられる。この点で Fe-S ク ラスターの役割は重要であるが，このクラスターの物性 で未だに不明瞭な点が多い。今後, 電子伝達の動力学的

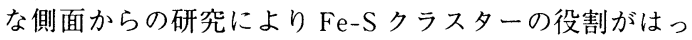
きりしてくるものと考える。また最近, 奥野による鉄一 硫黄蛋白モデルの詳しい総説があるので合わせて参照し て欲しい80)。

(昭和 62 年 2 月 16 日受理) 


\section{文献}

1a) G. Palmer, W. R. Dunham, J. A. Fee, R. H. Sands, T. Iizuka, T. Yonetani, Biochim. Biophys. Acta, 245, 201 (1971)

b) H. Blum. F. Adar, J. C. Salerno, J. S. Leigh, Biochim. Biophys. Res. Commun., 77, 650 (1977)

2a) B. C. Antanaitis, T. H. Moss, Biochim. Biophys. Acta, 405, 262 (1975)

b) A. J. Thomson, J. Chem. Soc. Dalton, 1981, 1180

3) R. A. Mathews, S. Charlton, R. H. Sands, G. Palmer, J. Biol. Chem., 249. 4326 (1974)

4) S. P. J. Albracht, J. W. van der Zwaan, R. D. Fontin, Biochim. Biophys. Acta, 766, 245 (1984)

5a) B. M. Hoffman, J. E. Roberts, W. H. Orme-Johnson, J. Am. Chem. Soc., 104, 860 (1982)

b) B. M. Hoffman, R. A. Venters, J. E. Roberts, M. Nelson, W. H. Orme-Johnson, ibid., 104, 4711 (1982)

6) J. A. Christner, E. Munck, T. A. Kent, P. A. Janick, J. C. Salerno, L. M. Siegel, ibid., 106, 6786 (1984)

7) R. E. Coffman, G. R. Buettener, J. Phys. Chem., 83. 2392 (1979)

8) J. M. Berg, R. H. Holm, "Iron-Sulfur Proteins" T. G. Spiro ed., Wiley, p. 1 (1982)

9) L. Que. Jr., J. R. Anglin, M. A. Bobrik, A. Davison, R. H. Holm, J. Am. Chem. Soc., 96, 6042 (1974)

10) R. J. Kassner, W. Yang, ibid., 96, 2109 (1974)

11a) E. T. Lode, C. L. Murray, J. C. Rabinowitz, J. Biol. Chem., 251, 1638 (1976)

b) R. S Magliozzo, B. A. Mclntosh, W. V. Sweeney, ibid., 257, 3506 (1982)

12) K. Tanaka, M. Masanaga, T. Tanaka, J. Am. Chem. Soc., 108, 5448 (1986)

13) N. Ueyama, T. Terakawa, M. Nakata, A. Nakamura, ibid., 105, 7098 (1983)

14) N. Ueyama, A. Kajiwara, T. Terakawa, S. Ueno, A. Nakamura, Inorg. Chem., 24, 4700 (1985)

15）上山憲一, 藤通 昭, 菅原 隆, 中村 晃, 第 35 錯塩討論会要旨 (広島) 372 (1985)

16) C. W. Carter, Jr., J. Biol. Chem., 252, 7802 (1977)

17) N. Ueyama, T. Terakawa, T. Sugawara, M. Fuji, A. Nakamura, Chem. Lett., 1984, 1287

18) T. O'Sullivan, M. M. Millar, J. Am. Chem. Soc., 107, 4095 (1985)

19) N. Ueyama, T. Sugawara, M. Fuji, A. Nakamura, N. Yasuoka, Chem. Lett., 1985, 175

20a) S. R. Dickman, A. A. Cloutier, J. Biol. Chem., 188, $379(1951)$ b) J. R. Morrison, Biochem. J., 58, 685 (1951)

c) F. Ruzicka, H. Beinert, J. Biol. Chem., 253, 2514 (1978)

21a) T. A. Kent, J. - L. Dreyer, M. C. Kennedy, B. H. Huynh, M. H. Emptage, H. Beinert, E. Munck, Proc, Natl. Acad. Sci. USA., 79, 1096 (1982)

b) M. H. Emptage, J. - L. Dreyer, M. C. Kennedy, H. Beinert, J. Biol. Chem., 258, 11106 (1983)

22) A. J. Thomson, J. Chem. Soc. Dalton Trans., 1981, 1180

23a) M. H. Emptage, T. A. Kent, M. C Kennedy, H. Beinert, E. Munck, Proc. Natl. Acad. Soc. USA., 80, 4674 (1983)

b) T. A. Kent, M. H. Emptage, H. Merkle, M. C. Kennedy, H. Beinert, E. Munck, J. Biol. Chem., 260, 6871 (1985)

24) M. K. Johnson, J. E. Morningstar, G. Cecchini, B. A. C. Ackrell, Biochem. Biophys. Res. Commun., 131, 756 (1985)

25) J. E. Morningstar, M. K. Johnson, G. Cecchini, B. A. K. Ackrell, E. B. Kearney, J. Biol. Chem., 260, 13631 (1985)

26) J. J. Maguire, M. K. Johnson, J. E. Morningstar, B. A. C. Ackrell, E. B. Kearney, ibid., 260, 10909 (1985)

27）八木達彦“バイオミメティックケミストリー”化 学総説 35, 学会出版センター, 173 (1982)

28) I. Okura, Coordination Chemistry Reviews, 68, 53 (1985)

29) G. Wang, M. J. Benecky, B. H. Huynh, J. F. Cline, M. W. W. Adams, L. E. Mortenson, B. M. Hoffman, E. Münck, J. Biol. Chem., 259, 14328 (1984)

30) H. Inoue, N. Fujimoto, E. Imoto, J. Chem. Soc. Chem. Commun., 1977, 412

31) H. Inoue, M. Suzuki, ibid., 1980, 817

32) H. Inoue, Y. Nagao, E. Haruki, ibid., 1985, 501

33) H. Inoue, T. Nagata, ibid., 1986, 1177

34) A. Nakamura, M. Kamada, K. Sugihashi, S. Otsuka, J. Mol. Cat., 8, 353 (1980)

35) R. S. McMillan, J. Renaud, J. G. Reynolds, R. H. Holm, J. Inorg. Biochem., 11, 213 (1979)

36) K. Tanaka, Y. Imanaka, M. Tanaka, M. Honjo, T. Tanaka, J. Am. Chem. Soc., 104, 4258 (1982)

37) M. Nakazawa, Y. Mizobe, Y. Mastumoto, Y. Uchida, M. Tezuka, M. Hidai, Bull. Chem. Soc. Jpn., 59, 809 (1986)

38) I. Okura, S. Nakamura, M. Kobayashi, ibid., 54, 3794 (1981)

39a) G. Christou, R. V. Hageman, R. H. Holm, J. Am. 
Chem. Soc., 102, 7600 (1980)

b) T. Yamamura, G. Christou, R. H. Holm, Inorg. Chem., 22, 939 (1983)

40) H. Tsai, W. V. Sweeney, C. L. Coyle, Inorg. Chem., 24, 2796 (1985)

41) N. Ueyama, T. Sugawara, A. Kajiwara, A. Nakamura, J. Chem. Soc., Chem. Commun., 1986, 434

42) M. Teixeira, I. Moura, A. V. Xavier, D. V. Der Vartanian, J. LaGall, H. D. Peck, Jr., B. H. Huynh, J. J. G. Moura, Eur. J. Biochem., 130, 481 (1983)

43) M. Teixeira, I. Moura, A. V. Xavier, B. H. Huynh, D. V. Der Vartanian, H. D. Peck, Jr., J. LaGall, J. J. G. Moura, J. Biol. Chem., 260, 8942 (1985)

44) S. W. Ragsdale, J. E. Clark, L. G. Ljungdahl, L. L. Lundie, H. L. Drake, ibid., 258, 3264 (1983)

45) S. W. Ragsdale, H. G. Wood, W. E. Antholine, Proc. Natl. Acad. Sci. USA, 82, 6811 (1985)

46) P. Giannoccaro, G. Vasapollo, A. Sacco, J. Chem. Soc., Chem. Commun., 1980, 1136

47）例えば中村 晃，上山憲一，有合化 39,1062 (1981)

48) S. S. Yang, W. H. Pan, G. D. Friesen, B. K. Burgess, J. L. Corbin, E. I. Stiefel, W. E. Newton, J. Biol Chem., 257, 8042 (1982)

49) W. E. Newton, F. A. Schultz, S. F. Gheller, S. Lough, J. W. McDonald, S. D. Conradson, B. Hedman, K. O. Hodgson, Polyhedron, 5, 567 (1986)

50a) S. P. Cramer, K. O. Hodgson, W. D. Gillum, L. E. Mortenson, J. Am. Chem. Soc., 100, 3398 (1978)

b) M. R. Antonio, B. - K. Teo, W. H. Orme-Johnson, M. J. Nelson, S. E. Groh, P. A. Lindahl, S. M. Kauzlarich, J. Am. Chem. Soc., 104, 4703 (1982)

c) G. Christou, K. S. Hagen, R. H. Holm, ibid., 104, 1744 (1982)

51) M. A. Walters, S. K. Chapman, W. H. Orme-Johnson, Polyhedron, 5, 561 (1986)

52) R. A. Venters, M. J. Nelson, P. A. McLean, A. E. True, M. A. Levy, B. M. Hoffman, W. H. OrmeJohnson, J. Am. Chem. Soc., 108, 3487 (1986)

53a) G. D. Watt, A. Burns, S. Lough, Biochemistry, 20, 7277 (1981)

b) S. Lough, A. Burns, G. D. Watt, ibid., 22, 4062 (1983)

54) G. D. Friesen, J. W. McDonald, W. E. Newton, W. B. Euler, B. M. Hoffman, Inorg. Chem., 22, 2202 (1983)

55) G. Christou, C. D. Garner, J. Chem. Soc., Dalton Trans., 1980, 2354

56) M. G. Kanatzidis, D. Coucouvanis, Acta Cryst.,
C39, 835 (1983)

57a) D. Coucouvanis, P. Premple, E. D. Simhon, D. Swenson, N. C. Baenziger, M. Draganjac, L. T. Chan, A. Simopoulos, V. Papaefthymiou, A. Kostikas, V. Petrouleas, Inorg. Chem., 22, 293 (1983)

b) B. - K. Teo, M. R. Antonio, B. A. Averill, J. Am. Chem. Soc., 105, 3751 (1983)

58) D. Coucouvanis, E. D. Simhon, P. Stremple, M. Ryan, D. Swenson, N. C. Baenziger, A. Simopoulos, V. Papaefthymiou, A. Kostikas, V. Petrouleas, In org. Chem., 23, 741 (1981)

59) D. Coucouvanis, E. D. Simhon, N. C. Baenziger, $J$. Am. Chem. Soc., 102, 6644 (1980)

60) T. E. Wolff, J. M. Berg, K. O. Hodgson, R. B. Frankel, R. H. Holm, ibid., 101, 4140 (1979)

61) E. I. Stiefel, R. Eisenberg, R. C. Rosenberg, H. B. Gray, ibid., 88, 2956 (1966)

62) T. E. Wolff, J. M. Berg, R. H. Holm, Inorg. Chem., 20, 174 (1984)

63) S. R. Scott, G. Christou, C. D. Garner, T. J. King, F. E. Mabbs, R. M. Miller, Inorg. Chim. Acta, 35, L337 (1979)

64) M. G. Kanatzidis, D. Coucouvanis, J. Am. Chem. Soc., 108, 337 (1986)

65) B. J. Weathers, J. H. Grate, N. A. Strampach, G. N. Schrauzer, ibid., 101, 925 (1979)

66) A. E. Shilov, N. T. Denisov, O. N. Etimov, N. F. Shuvalov, N. I. Shuvalova, A. K. Shilova, Nature, 231, 460 (1971)

67) K. Tanaka, Y. Hozumi, T. Tanaka, Chem. Lett., 1982, 1203

68) M. Hidai, “Molybdenum Enzymes” , T. G. Spiro, ed., Wiley, New York, 285 (1985)

69) J. Chatt, J. R. Dilworth, R. L. Richards, Chem. Rev., 78, 589 (1978)

70) N. Ueyama, H. Zaima, H. Okada, A. Nakamura, Inorg. Chim. Acta, 89, 19 (1984)

71）岡田啓子, 在間弘朗, 菅原 隆, 上山憲一, 中村 晃，第 33 錯塩討論会要旨 (大阪) 202 (1983)

72) M. J. Barber, L. M. Siegel, Biochemistry, 22, 618 (1983)

73) G. N. George, T. R. Hawkes, G. D. Jones, R. C. Bray, Polyhedron, 5, 587 (1986)

74) J. L. Johnson, K. V. Rajagopalan, Proc. Natl. Acad. Sci. USA, 79, 6856 (1982)

75a) W. E. Newton, J. L. Corbin, D. C. Bravard, J. E. Searles, J. W. McDonald, Inorg. Chem., 13, 1100 (1974)

b) R. Barral, C. Bocard, I. Seree de Ruch, L. Sajus, 
Tetrahedron Lett., 17, 1693 (1972)

76) N. Ueyama, M. Yano, H. Miyashita, A. Nakamura, M. Kamachi, S. Nozakura, J. Chem. Soc. Delton Trans., 1984, 1447

77) N. Ueyama, E. Kamata, A. Nakamura, Chem. Lett., 1982, 947

78a) J. M. Berg, R. H. Holm, J. Am. Chem. Soc., 107, 917 b) J. P. Caradonna, E. W. Harlan, R. H. Holm, ibid., 108, 7856 (1986)

79) N. Ueyama, K. Kamabuchi, A. Nakamura, J. Chem. Soc. Dalton Trans., 1985, 635

80）奥野洋明, 有合化, 45, 123 (1987)

\section{次号予定}

巻 頭 言

製薬企業の研究開発者に望まれるもの .野 田寛 治

\section{総説および総合論文}

硫黄官能基で活性化されたピリジン環および関連複素環化合物の反応…….........................古 川 尚 道

合成ペプチド脂質一会合形態とその酵素機能モデルとしての反応場特性……......................村 上 幸 人

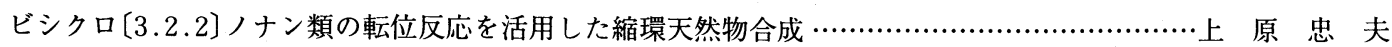

トリフルオロメチル基を有する合成ピレスロイドの新規合成法…….................................藤 田 誠

檜山為次郎

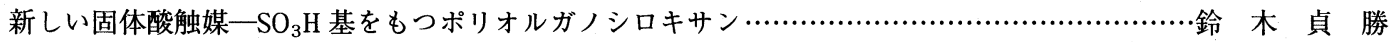

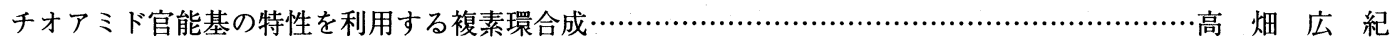

\section{技術発達史}

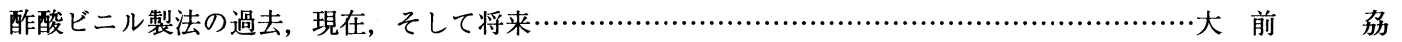

ケミカルス覚え䡒き

過酸酢

十字 路

ホロ酵素

集積反応場

ベシクル・ラメラ・ミセル

かご効果

シグマトロピー転位

上 原 忠 夫

$\mathrm{S}_{\mathrm{N}}{ }^{\prime}$ 型反応

.檜 山 為次郎

Lawesson 試薬と Meerwein 試薬

Electron-inversed Demand Diels-Alder 反応

.山 崎 高 應

固体酸の酸量と酸強度.......

小野 嘉夫

\section{REVINDEX 新しい合成，ほか}

